This item was submitted to Loughborough's Research Repository by the author.

Items in Figshare are protected by copyright, with all rights reserved, unless otherwise indicated.

\title{
Postfordism as a dysfunctional accumulation regime: A comparative analysis of the USA, the UK and Germany
}

PLEASE CITE THE PUBLISHED VERSION

https://doi.org/10.1177/0950017013481876

\section{PUBLISHER}

(C) The authors. Published by SAGE Journals

\section{VERSION}

AM (Accepted Manuscript)

\section{PUBLISHER STATEMENT}

This work is made available according to the conditions of the Creative Commons Attribution-NonCommercialNoDerivatives 4.0 International (CC BY-NC-ND 4.0) licence. Full details of this licence are available at: https://creativecommons.org/licenses/by-nc-nd/4.0/

\section{LICENCE}

CC BY-NC-ND 4.0

\section{REPOSITORY RECORD}

Vidal, Matt. 2019. "Postfordism as a Dysfunctional Accumulation Regime: A Comparative Analysis of the USA, the UK and Germany". figshare. https://hdl.handle.net/2134/27599. 
Postfordism as a dysfunctional accumulation regime: A comparative analysis of the US, UK and Germany

\author{
Matt Vidal \\ King's College London \\ Department of Management \\ 150 Stamford St
}

London SE1 9NH

\begin{abstract}
The article seeks to reanimate the early regulation theory project of building Marxist political economy through the development of mid-range institutional theory. The concept of a mode of regulation - central to the Parisian wing of regulation theory - is rejected in favour of a distinction between functional and dysfunctional accumulation regimes. The Fordist regime of accumulation provided a unique institutional context allowing an extraordinary combination of high profits, rising real wages and strong GDP growth. In contrast, the postfordist regime is shown to be inherently dysfunctional, characterised by manifest tendencies toward stagnation and associated regressive trends in work and employment relations. A comparative analysis of profit rates, wage shares, growth rates and debt in the US, UK and Germany shows that the single model of a dysfunctional postfordist accumulation regime fits all three countries, although with important differences in forms of dysfunctionality.
\end{abstract}

\title{
Keywords
}

Accumulation regimes, crisis, debt, debt-led growth, deunionisation, financialization, Fordism, job polarisation, Marxism, regulation theory, postfordism 
During the 1980s and '90s the concepts of Fordism and postfordism animated lively debates in the sociology of work. Many accepted Fordism as a good characterisation of traditional mass production and the wider institutional context of the 1950s and '60s. However, some influential scholars developed a theory of postfordism promising industrial regeneration through post-Taylorist forms of work organisation and decentralised production, prompting heavy criticism in the pages of this journal (Dawson and Webb, 1989; Smith, 1989; Williams et al., 1992; Thompson, 2003). In particular, various 'postfordist scenarios' (Thompson, 2003) were seen as inconsistent with the diversity of employment arrangements in advanced capitalism, including regressive trends such as declining employment security, work intensification and rising inequality. At the same time, there were calls in this journal for moving beyond labour process analysis to examine how work and employment relations shape and are shaped by larger dynamics of capitalist accumulation (Hyman, 1987; Thompson, 2003) and class relations (Crompton, 2010).

The argument of this article is that while critics of utopian versions of postfordism were largely correct, they tossed the baby out with the bathwater. The bathwater consisted of approaches that took the Fordism/postfordism framework from its critical, Marxist roots and recast it as a theory of industrial regeneration, most influentially the theory of flexible specialisation (Piore and Sabel, 1984). The baby was that very critical, Marxist framework - regulation theory - which saw Fordism as a unique period of class compromise, rooted in Taylorist mass production, providing two decades of strong growth with rising real wages. This article argues that the regulationist research program continues to provide a unified theoretical framework for analysing the interrelations 
between labour processes, employment relations, corporate forms, class relations and accumulation dynamics. But it also criticises and rejects a core concept of the Parisian wing of regulation theory - the 'mode of regulation' - which was a key theoretical development marking a broader shift in regulation theory from an approach in which stable and strong growth under capitalism was viewed as an unlikely and remarkable feat to one preoccupied with searching for a new mode of regulation to anchor strong growth (Lipietz, 1992; Boyer and Saillard, 2002b).

The article begins by responding to the core criticisms of the concept of postfordism elaborated in this journal. The second section develops a distinction between functional and dysfunctional accumulation regimes by integrating regulation theory with other approaches to Marxist political economy. The argument developed here is that Fordism was a uniquely functional (but not functionalist) accumulation regime in its ability to temporarily contain inherent capitalist tendencies toward stagnation, but these have now been permanently unleashed under postfordism which, as such, is a dysfunctional regime. This dysfunctional regime provides the structural context within which deunionisation and employment externalisation have led to polarised job growth. The final section presents a comparative analysis of profit rates, wage shares, growth rates and household debt in the US, UK and Germany. The outcome shows that the single model of a dysfunctional postfordist accumulation regime fits all three countries, although with important differences in forms of dysfunctionality. As such, regulation theory provides an alternative framework to the varieties of capitalism approach, which, in its exclusive focus on institutional difference, tends to obscure the common nature of capitalist economies. 


\section{Postfordism as a model of production}

The conceptual apparatus of Fordism and postfordism was developed by French régulation theorists as a research program of mid-range, institutionalist Marxist political economy. Based on the US case, Aglietta (2000 [1979]) articulated a multilevel conceptualisation in which Fordism was both a model of production - mass production of standardised products with a Taylorist division of labour - and a macroeconomic regime of accumulation in which mass production was matched with mass consumption by institutionalising a class compromise via unionisation and the welfare state. The Fordist regime generated strong growth and rising real wages from the end of WWII to the late 1960s, but then experienced declines in profits, productivity and growth. Following Palloix (1976), Aglietta suggested that the organisational response was likely to be neofordism: mass production combining flexible automation with the new flexible working arrangements going under names such as job enlargement and group work.

In an influential book, Sabel (1982: 220) shifted the focus of the framework from its critical emphasis on neofordism to a more optimistic, prescriptive approach focused on the notion of a post-Taylorist model inspired by the neocraft 'high-technology cottage industry’ of the Italian industrial districts. In a later, even more influential book with Piore (1984), they developed the same arguments but shed the language of Fordism and introduced the concept of flexible specialisation. As Smith (1989) perceptively noted, the terminological shift was not simply semantic; flexible specialisation was meant to be a more encompassing concept, going beyond the industrial districts of Italy to include 
incipient changes in mass production sectors, thus narrowing the distance between Fordism and flexible specialisation.

A few early contributions in WES were more sympathetic to the arguments of Piore and Sabel, in particular Streeck (1987) and Lane $(1988: 165,167)$ who saw merit in the post-Taylorist model but were sceptical about the possibility for its widespread adoption, particularly in countries like the UK with an entrenched history of Taylorism. The more common reception in WES was to be deeply critical of this framework, seeing flexible specialisation as the leading postfordist alternative to the neofordism. Dawson and Webb (1989) argued that the flexible specialisation thesis was problematic because it assumed the dominance of a single organisational model based on manufacturing. Smith (1989: 216) observed similarly that 'industrial diversity is endemic to capitalist competition and reflects the separation of capitals, and the costs attached to innovation and inertia.' For Thompson (2003: 359, 361) Fordism was 'the least worst term available to describe a set of social relations that manifest a degree of connectedness and coherence.' In contrast, 'Post-Fordist scenarios’ were 'not only radically at odds with reality; they are, as widely observed, lacking any analytical or empirical coherence.' Rather than radical continuity proposed by postfordist theories, there has been a partial break with Fordism. Managers attempt to gain more mental effort and commitment from workers to engage in flexible work practices, but are unable to reciprocate commitment and provide security because of increased market pressure due to the rise of shareholder value, deregulation and internationalisation.

In sum, postfordism has been criticised for using a single model of production based on manufacturing to explain broad societal change, thus being unable to deal with 
empirical diversity; for proposing radical discontinuity between paradigms, thus missing important elements of continuity; and for being utopian. The latter two criticisms are more easily dealt with. Utopian formulations are indeed problematic but they were simply one vein in the development of the broader analytical framework. But why continue with the terminology rather than adopting something with less baggage?

Because Fordism refers to a unique institutional period in the history of capitalism in which the ravages of market competition were tamed. Using the concept of postfordism, shorn of utopian or monolithic formulations, helps bring the uniqueness of the Fordist period - and the problems of postfordism - into sharp relief. And it captures the institutional interconnectedness between trends such as tertiarisation, financialization and neoliberalism. This simply need not imply a radical break. Post simply means ‘after’ and there is no theoretical reason why such a conception cannot include elements of continuity and change. Within manufacturing, lean production is the predominant postfordist production model, which includes continuities in terms of neotaylorism and mass production, but is new and distinct in three respects: demand-driven rather than supply-driven production, vertical disintegration rather than vertical integration, and diversified rather than standardised output (Vidal, 2011). Beyond manufacturing, as will be argued below, there are important additional elements of discontinuity in the shifting international division of labour, state intervention, employment relations and forms of competition.

The third criticism is sound: a singular model of production based on a particular manufacturing labour process does not provide a good basis for distinguishing between economic periods. Rather than seeing Fordism and postfordism as particular types of 
labour process, they are better conceptualised as accumulation regimes within which a variety of distinct labour processes and employment relations may be established (Vidal, forthcoming). In our view, the theory of accumulation regimes provides a basis for analysing the interconnections between trends in work, employment relations, accumulation dynamics and class relations, allowing for diversity of arrangements but focusing attention on how structural pressures common to capitalism are filtered through and shaped by particular institutional configurations.

\section{Theoretical reconstruction: Postfordism as a dysfunctional accumulation regime}

\section{Functional versus dysfunctional regimes of accumulation}

Marx (1992 [1885]) anticipated the ‘Keynesian’ problem of effective demand with his discussion of the problem of ensuring balance between what he called Departments I and II, respectively, the producer goods and consumer goods sectors. Aglietta (2000 [1979]) examined the US case to show how expanded reproduction - relatively stable, internally driven growth - could happen only when there was balance between the two departments. Such balance was achieved historically through a transition from an extensive to an intensive regime of accumulation: from a period of uneven development in the productive forces focused heavily on the producer goods sector, whose main markets were agricultural industries and infrastructure development, to one where capitalist production spread to the consumer goods sector, thus extending commodification by establishing a norm of market-based consumption. The Fordist regime established intensive growth based on rising real wages (hence mass consumption) via a class compromise with unions and vertically integrated, internalised employment. 
For Aglietta (2000 [1979]), the analysis of expanded reproduction through the theory of regulation is a crisis approach offering a complete alternative to equilibrium theory. The term 'mode of regulation' did not appear in Aglietta’s 1979 text, where he used the concept of accumulation regime to refer to the entire social formation in a given period. In terms of English language publications, Boyer (1979) introduced the idea in a foundational article where he distinguished a competitive régulation - written as a noun, like a mode of regulation - from a monopolistic régulation. In the former, wages do not follow productivity growth, so real wage growth has to occur through price reductions. In the latter, explicit wage indexation became standardised through collective bargaining. Boyer's argument about types of regulation of wage determination was compelling and his body of work is remarkable, contributing numerous theoretical advances and empirical insights. But the growth model he developed is deeply problematic. In this model (Boyer, 1988; Boyer and Saillard, 2002a; Boyer and Saillard, 2002b), strong growth is achieved only when an underlying accumulation regime becomes stabilized and guided by a mode of regulation. The latter is realized only when coherent interrelations are established across five institutional domains: work and employment relations, forms of competition, money and credit, the state and the insertion of the national economy into the international system. But given the myriad ways in which the variety of institutions would have to cohere, such a formulation is not empirically viable. In theoretical terms, the ontological or analytical status of the distinction between 'regularities' of the underlying regime and the 'institutional forms' of its mode of regulation (Boyer, 1988: $71,75)$ is vaguely elaborated and remains unclear. 
In place of this distinction we propose a distinction between functional and dysfunctional accumulation regimes. Rather than seeing institutions as distinct from an underlying accumulation regime, in our formulation accumulation regimes are constituted by the full range of institutions relevant to supporting or hindering capital accumulation, including the five institutional domains of regulation theory, but with no expectation that the various institutions will congeal into anything resembling a coherent mode of regulation. We develop the theory through engagement with other approaches to Marxist political economy.

Profit is the basis of capitalism. The higher the average profit rate, the more attractive investment, and vice versa. If the rate of profit is falling, it will increasingly discourage investment, hence output and employment. The central source of the tendency of the rate of profit to fall for Marx was the rising technical composition of capital, that is, increasing physical capital per unit of labour input. If surplus labour is the source of profit, and competition spurs capitalists to substitute machines for labour, this will put downward pressure on profits, hence undermining the basis of the system. Many Marxists (e.g. Shaikh, 1978) argue that Marx correctly saw the tendency of the rate of profit to fall, driven by the rising technical composition of capital, as the central crisis tendency of capitalism. However, Clarke (1990-1991: 448) persuasively argued that the central crisis tendency under capitalism - the one that makes crises a necessary feature of the system derives from a tendency toward overproduction, itself an outcome of 'the contradiction between the tendency for capital to develop the productive forces without limit ... and the tendency to restrict the consumption power of the mass of the population, by displacing 
living labour, forcing down the value of labour-power and expanding the reserve army of labour.'

Continuing with Clarke’s (1990-1991: 453) interpretation, the falling rate of profit is not the source of crisis but a tendency that intensifies the above contradiction. Overproduction is an inherent tendency because capitalists experience limits in the market, 'barriers to the production and realisation of surplus value,' as 'barriers to be overcome.' Fuelled by credit, capitalists will attempt to overcome the limit of the market by expanding production, and some will be successful in expanding it by making cheaper products or creating new ones, but the economy will always hit a new limit as innovations are generalised. In aggregate, the tendency to overproduction can take the form of either a glut of commodities or imbalances (disproportionalities) in capacity between departments and sectors, as more dynamic sectors develop the forces of production more rapidly. This results in periodic crises of overaccumulation - a surplus of capital with a lack of sufficient outlets for investment - in which capital is devalued, capacity destroyed and unemployment increased through bankruptcies, mergers and acquisitions. Such crises set the stage for renewed profitability and accumulation.

The tendency toward overproduction is permanently manifest through 'the class struggle over the production of surplus value, and the competitive struggle over its realisation’ (Clarke, 1990-1991: 465). Although Clarke does not explicitly elaborate it as such, the implication is that class struggle may generate more contingent crisis tendencies, either a profit squeeze due to high wages or underconsumptionism, depending on who is prevailing. Underconsumptionism in this analysis is not the crude version based on a theory of consumer demand as the ultimate purpose of capitalism, an 
argument vehemently rejected by some Marxists (e.g. Kliman, 2012) who correctly insist that surplus value is the primary drive of capitalism. Rather, underconsumptionism is a contingent expression of the necessary tendency toward overproduction.

Based on this reading we elaborate a distinction between accumulation regimes that are functional, dysfunctional or in crisis. This terminology should not be confused with functionalist reasoning. It is simply a way of distinguishing between accumulation regimes that are prosperous from those that are stagnant, not an argument that certain institutions exist due to the functions they serve for the system.

Following Harvey (2010), the term crisis is reserved for periods of severe slowdown in growth, typically associated with bubbles (due to speculation with surplus capital and/or disproportionate growth fuelled by loose credit), and always followed by large-scale devaluation of capital. Harvey noted that global crises fitting this description have occurred in 1848, 1929, 1973 and 2008, the latter of which has resulted in losses of \$50 trillion in asset values so far. If we want to reserve the term crisis to refer to extended recessions resulting in extensive bankruptcies, the destruction of capital value and widespread corporate restructuring, then it makes sense to refer to the other tendencies associated with crisis theory as something else. We suggest stagnation tendencies, referring in particular to the rising technical composition of capital, a profit squeeze and underconsumptionism. Each generates fragility, instability and stagnation, intensifying the contradiction between the tendencies toward overproduction and the restriction of consumption power.

Marx and subsequent Marxists have also discussed countertendencies (elaborated in the following section) to what we call stagnation tendencies; hence an accumulation 
regime is functional when all of the stagnation tendencies have been offset. In such a context the economy will grow at steady rate, likely well above $3 \%$ per annum that is deemed 'normal' growth among mainstream economists. The stagnation tendencies may become manifest, however, without developing into a full-blown crisis. An accumulation regime is dysfunctional when there is evidence that one or more stagnation tendencies are no longer being offset, but the economy remains out of crisis for an extended period of time.

In addition to the stagnationist tendencies of a low profit rate or underconsumptionism, we argue that a third is debt-led growth, an idea borrowed from Kaleckian macroeconomics (Onaran et al., 2010; Stockhammer, 2012). Briefly, Kaleckians distinguish investment-led regimes, where investment demand can internally drive growth and compensate for declining consumer demand, from wage-led regimes, where investment-demand does not compensate for declining consumer demand. Debtled regimes are wage-led regimes in which consumer credit plays a significant role sustaining consumer demand. Debt-led regimes are fragile because high debt servicing levels mean that even temporary reductions in income will lead to increasing defaults (Stockhammer, 2012). Finally, there are also export-led regimes, where exports are a significant component of demand.

Based on the manifestation of stagnation tendencies, we define the following three forms of dysfunctional accumulation: A declining or historically low profit rate along with an associated rise in the capital/labour ratio (TCC) or the wage share (profit squeeze); underconsumptionism, as indicated by declining or historically slow growth (growth below 3\% p.a.) along with a decline in the wage share; and debt-led growth, as 
indicated by moderate growth levels and a declining wage share offset by rising/high household debt levels.

\section{The Fordist and postfordist accumulation regimes}

The model of Fordism and postfordism developed in this section is heavily based on our in-depth analyses of the US (Vidal, 2012; Vidal, forthcoming), but we believe the general outlines of the model will hold for the UK and Germany, although with distinct institutional configurations within the general model. Our main goal here is to develop a general theoretical model of the postfordist accumulation regime and present a comparative macroeconomic analysis for all three countries in support of this model. Indepth institutional analysis on the UK and Germany will have to await future research.

The Fordist accumulation regime is defined here as a nationally-bound, massproduction based economy with producer-driven supply chains, oligopolistic competition in core sectors and a Keynesian welfare state. The canonical case was the US, in which the structural context allowed a class compromise between capital and labour, led by the big three auto companies and the United Auto Workers and diffused through pattern bargaining, in which wages were indexed to productivity, allowing a satisfactory profit rate and economy-wide rise in real median wages (Vidal, 2012). West Germany and the UK developed a similar structural context, the former realising class compromise rooted in family-oriented Christian Democracy (Gottfried, 2000), the latter largely failing to reach a sustained class compromise over production control and wages (Tickell and Peck, 1992). 
In the US case, there is strong evidence that the Fordist regime effectively offset the various crisis and stagnation tendencies for 15 or so years. The profit rate in the Fordist period was high initially because it followed a massive decline in the value of physical capital and the nominal value of financial assets during the Great Depression and WWII (Kliman, 2012). A rise in the organic composition of capital was offset by a continuous rise in productivity (Wolff, 2003) generated by intensive growth (Aglietta, 2000 [1979]), underconsumptionism offset by rising real wages (Lipietz, 1986) and overproduction moderated through nationally-bound, oligopolistic competition, again with balanced growth via standardised mass production and institutional supports for mass consumption (Aglietta, 2000 [1979]). On the profit rate decline, Shaikh presented evidence for the US (1987) and Duménil and Lévy (2004) for the US, Germany, France and the UK, showing a rising technical composition of capital. Wolff (2003) and Mohun (2009) provided evidence that the US profit rate decline was driven both by a rising technical composition of capital and a profit squeeze. Glyn and colleagues (2007) presented data showing a profit squeeze due to full employment for the US, France, Germany, Italy, the UK and Japan. With a secular decline in profit rates across the OECD beginning in the mid to late 1960s, Fordism transitioned into a dysfunctional regime.

In response to Fordist stagnation, corporations engaged in widespread restructuring, accelerating the changing division of labour through global outsourcing and diversification of large corporations into a range of service sectors, resulting in a shift in power from manufacturing firms toward large retailers controlling global supply chains (Vidal, forthcoming). This corporate restructuring (along with technical change) ushered 
in the postfordist accumulation regime, which is service-based with buyer-driven, internationalised commodity chains, intensified, wage-driven competition even in core sectors and a neoliberal state. On the shift to services, the top ten US employers in 1955 were all manufacturers, while the top 25 in 2011 included only two manufacturers, seven general merchandisers and three restaurant companies (Vidal, forthcoming).

Because there is no such thing as a coherent mode of regulation, accumulation regimes cannot be dated with precision. It takes many years - around a decade in our analysis - before institutional transformations such as internationalisation, tertiarisation and financialization settle into new configurations. While closely interrelated, such institutional transformations happen through a diffuse array of organizational changes that are coterminous neither within nor across national accumulation regimes. But we can roughly date Fordism from 1945 through the early 1970s when profit rates were rapidly declining in all three countries, stagflation kicked in, the Bretton Woods system of fixed exchange rates collapsed and firms began a wave of restructuring to recover profitability and increase flexibility. As a matter of convenience, we might date the consolidation of postfordism in these three countries from 1982-83. As the empirical analysis in the following section will show, in a quite remarkable convergence all three countries experienced a turnaround in the profit rate decline in this two-year period (Germany and the UK in 1982, the US in 1983), although none experienced a sustained recovery to Fordist rates.

A central focus of regulation theory is the historical process of changing articulation among institutional domains (Boyer, 2000). What is commonly referred to as the standard model of employment - full time, long-term employment with a single 
employer, including security and opportunities for training and promotion - is something historically specific to the Fordist regime. This model was made possible because competition and finance were subordinated to work and employment relations, the former through oligopolistic competition in the core manufacturing sector, the latter because Fordism still provided opportunities for intensive growth and profit based on mass consumption. Among the institutional shifts in the postfordist regime are that core employers are now large service firms and supply chains buyer-driven, and that competition and finance have come to dominate employment relations in new ways, most importantly by putting wages, even for core firms, back at the centre of competition.

In terms of employment, Fordism was characterised by a logic of internalised employment relations, meaning that best business practice was understood to include vertically-integrated firms with internal labour markets, including detailed job ladders with well-defined training and promotion opportunities, and administratively-determined wages associated with positions rather than individuals. The pressure of the declining profits provided the context within which intensified competition and financialization began to shape employment relations. In particular, the internationalisation of production and the rise of the shareholder value model of the firm (Lazonick and O'Sullivan, 2000) combined to generate a new predominant logic of externalised employment relations, that is, outsourcing and deunionisation, reducing employment security, training and promotion opportunities, and returning to market-determined wages (Vidal, forthcoming). The shareholder value model ensured that the externalisation logic took hold even in core service sectors like retail sales, leisure and hospitality that are 
ostensibly more shielded from international wage competition than jobs subject to offshoring.

In addition to the shareholder value revolution and the dramatic rise in power of financial markets, workers’ revenue has become financialized via credit-financed consumption, allowing banks to extract profit directly from wages (Lapavitsas, 2011: 615, 618). We agree with Lapavitsas that financialization is not a simple 'triumph of the rentier over the productive capitalist' as post-Keynesians have argued, but still plays a critical role in mobilising capital for the accumulation process. However, we disagree with his rejection of the argument that financialization is also in part an attempt to generate profits in response to overproduction. Total capacity utilisation in the US averaged $87.2 \%$ from $1967-69,82.8 \%$ in the 1970 s, $79.6 \%$ in the 1980 s, $82.4 \%$ in the 1990s and $77.4 \%$ in the 2000s. ${ }^{1}$ As Marx argued, 'accumulation comes up against difficulties of application, against a lack of spheres of investment, i.e. if branches of production are saturated and loan capital is over-supplied, this plethora of loanable money capital proves nothing more than the barriers of capitalist production’ (Marx, 1981 [1894]: 639, his emphasis). Indeed, daily trading on world currency markets skyrocketed from \$18 billion per day in 1977 to $\$ 1.8$ trillion per day by 2008, in 2004 the daily turnover of foreign exchange and interest rate derivative contracts was \$2.4 trillion, and in 2005, $92 \%$ of futures contracts were on financial instruments with only $8 \%$ on commodities (Foster and Magdoff, 2009). These data provide strong support for the argument that overcapacity and overaccumulation were key drivers of financialization.

\section{Comparative analysis of postfordist accumulation regimes}


We use all available data back to 1945, but there are differences in availability for particular series in each country. On profit rates, we follow Kliman (2012) in using corporate profit as a proportion of net capital stock at historical cost for the US and UK. However, because data specific to the corporate sector are not available for many other countries (including Germany), we also present a broader measure of the profit rate using net operating surplus of the total economy as a proportion of private net stock, excluding dwellings and government services. While the latter measure is only a rough estimate, we are interested in trends and the two measures are effectively identical regarding trends for both the US and UK. So we are relatively confident in using the broader measure for Germany.

\section{[FIGURES 1-3 HERE]}

As shown in Figure 1, US corporate profit rate was high from 1945 to 1965, averaging 21\%, began a steady decline from 1965 to a trough of 9\% in 1982 (averaging 15\% the latter period), rising from that trough to a post-1970s peak of 16\% in 1997 and 18\% in 2006, but only averaging 13\% between 1983 and 2006. Figure 2 presents profit rates for the UK. Following the extensive damage inflicted in Britain during WWII, the UK corporate profit rate was abnormally high at $44 \%$ in 1950, falling more or less continuously until hitting a low of just $8 \%$ in 1975 . It remained at or below $10 \%$ until 1981, after which it began a slight recovery with peaks of $13 \%$ in $1985,15 \%$ in 1997 , and 16\% in 2007 as the global financial crisis began. Figure 3 presents three different estimates for Germany, again based on data availability. By the broad measure, it peaked 
at $16 \%$ in 1963 and again at 16\% in 1968, then dropped steadily to a trough of $8 \%$ in 1981, thereafter recovering slightly to a peak of $10 \%$ in 1994 , the last year for which there are data on these measures. Based on the same numerator and a similar denominator measuring private fixed capital, the German profit rate recovered slightly further to $11 \%$ in 2007.

\section{[FIGURE 4 HERE]}

Figure 4 shows the share of labour's income (total compensation) in total national income. The wage share for the US peaked at 68\% in 1982 and fell to troughs of $64 \%$ in 1997 and 63\% in 2010-11. The wage share did bump up to 66\% in 2001-2, reflecting the hit to profits from the 2001 recession ending the decade-long 1990s boom; apparently firms were not able to lay off workers fast enough to sustain profits. Importantly, however, nonwage forms of compensation have risen more quickly than wages, meaning that the actual income received by employees has dropped even more sharply, from a peak of 60\% in 1970 to 51\% in 2005 (Kliman, 2012: Figure 8.1).

In the UK, labour's share averaged 66\% from 1960-73, spiked briefly to 74\% in 1975 before dropping to an average of $68 \%$ over $1977-80$ and then dropping to troughs of $58 \%$ in 1997 and $60 \%$ in 2008 . The average for the period from $1960-80$ was $67 \%$ versus $62 \%$ for 1981-2011. The spike in labour's share from 1973-75 reflects the hit on profits from the deep recession beginning in 1973 and likewise the 1991 recession produced a brief bump in labour's share. In Germany labour's share rose steadily from a much lower 
point of 50\% in 1960 to a peak of 65\% in 1981 and another peak of 66\% in 1993, falling after that to a trough of $57 \%$ in 2007.

These data provide support for Lipietz’s (1982) argument that in response to the declining profit rate capital began a sustained and multipronged assault on labour, attempting to recover profits in part through increasing the profit share. In the US the wage share dropped from $60 \%$ in 1970 to $51 \%$ in 2005 , but the drop in total compensation was smaller. A substantial part of rising nonwage compensation in the US is health care costs, which are uniquely high among advanced capitalist economies due to the waste involved with myriad 'free market' insurance companies and private HMOs. Additionally, Mohun (2006) showed that a rise in the rate of surplus value after 1979 went almost entirely to the wages of supervisors. Thus, even though capital attacked labour's wages, there has been no sustained recovery of the profit rate to Fordist levels in the US. In the UK the profit rate had a slight recovery after 1980, and the data suggest that a decline in labour's share helped drive the slight reversal of the long decline, although the UK private sector also failed to see a sustained recovery, its profit rate averaging just 12\% over the 1981-2009 period. In Germany there has also been no sustained recovery of the profit rate to Fordist levels, although an upward trend began in 1981 with a faster rise starting in 1993. The decline in German labour's wage share did not occur until later that the other countries, with a sharp decline in 1993, dropping 9 percentage points by 2007, providing a boost to the profit rate.

We now turn to examine the labour market mechanisms employers used to reduce labour's share of income, before turning back to the question of growth and the dysfunctionality of the postfordist regime. Figure 4 also charts union density rates 
alongside the wage share. In all three countries a visual inspection suggests the two trends are closely linked, particularly for the postfordist period. Indeed, the simple correlation for union density and labour's share between 1975-2010 is .63 for the US, .71 for the UK and .72 for Germany. While the correlation, of course, says nothing about causality, these correlations are consistent with the standard understanding of unions as organisations designed to bargain for increases in member wages. The higher correlations in the UK and Germany likely reflect the more powerful unions and higher levels of bargaining in these countries, as against the weaker and more decentralised US union movement. The UK had multiemployer agreements that set minimum terms and conditions within sectors and industries until the 1980s, and Germany the same until more recently, suggesting that unionisation matters more for wage setting across the economy. In the US, with only $25 \%$ of the workforce covered by union contracts in 1975 , employers were freer to reduce wages without having to gain concessions from unions.

We argued above that the postfordist regime in the US has seen a shift from a dominant logic of employment internalisation, including opportunities for promotion and administratively-determined wages, to one of externalisation, including flatter organisational structures due to outsourcing and downsizing and market-determined wages. Evidence of such externalisation is found in polarised job growth. Wright and Dwyer (2003) presented evidence on the US comparing the decades of the 1960s to the 1990s. They found that growth was, respectively, 2 versus 17 per cent in the lowest jobquality decile, 30 versus 11 per cent in the middle two deciles, and 40 versus 50 per cent in the top three deciles. Goos and Manning (2007) presented evidence on the UK showing that job growth from 1979 to 1999 was entirely concentrated in the bottom two 
and top two wage deciles. Goos and collaborators (2009) presented data on the UK and Germany. Examining changes in shares of hours worked over 1993-2006 for the four lowest paying occupations, the nine middling and the eight highest paying occupations, they found rates, respectively, of 5.8, -10.3 and $4.6 \%$ for the UK, and 3.1, -8.7 and 5.7\% for Germany. Fernández-Macías (2012) presented further evidence of change in employment levels from 1995-2007, showing that UK job growth was concentrated in the second lowest and top two wage quintiles, and that German job growth was entirely concentrated in the bottom one and top two quintiles.

Such patterns of job polarisation are consistent with widespread employment externalisation by corporations. In the US case, there is extensive quantitative and qualitative evidence (reviewed in Vidal, forthcoming) that employers have been reorganising work by outsourcing and reducing job classifications with lean staffing strategies. This, along with the broader transition to a service economy, has generated a rise in entry-level jobs with no training or promotion opportunities. Concurrent with this has been the broader transition to a service-based economy. The extent to which corporate employment strategy and the occupational structure of the UK and Germany are similar to the US will have to await future research, but the data on declining wage shares and rising job polarisation in the UK and Germany are strongly suggestive of common underlying institutional labour market trends.

[FIGURES 5 \& 6 HERE] 
Finally, what has been the effect of declining shares for labour on growth? Is there evidence of a problem of underconsumptionism? Figure 5 presents decennial GDP growth rates. By the mainstream standard of 3\% as normal, Fordist growth in the US and the UK was well above normal (data were not available for Germany). The US managed to maintain moderate levels of 3.2\% over the 1970 s, ' 80 s and ' 90 s but experienced a dismal $1.8 \%$ in the 2000s. The UK has come in below 3\% in each of the decades since the 1960 s with just $2.03 \%$ in the 2000 s. Germany managed $3.08 \%$ in the 1970 s but hovered around $2 \%$ in the ' 80 s and ' 90 s, dropping to just $1.15 \%$ in the 2000 s. These data indicate that the UK and Germany have been stagnationist for the entirety of their postfordist regimes while the US was able to achieve moderate growth for much the first two decades of the postfordist regime before it became fully stagnationist in its third decade.

As Figure 6 shows, between 1995 and 2007, the debt-to-income ratio rose by 49\% in the US and $70 \%$ in the UK. In contrast, the ratio has been essentially stable in Germany, rising only by 4\%. These data are evidence of the financialization of workers’ revenue (Lapavitsas, 2011) in the US and UK, but not in Germany. A common suggestion regarding low debt in Germany is that memories of Weimar inflation have stoked fears 'that excessive debt-financing would spark inflation' and so Germans have 'stuck rigidly to neoliberal orthodoxies’ (Harvey, 2010: 141). Perhaps, but explanations based on national culture are suspect. A more structural explanation would be Germany’s comparatively low homeownership rate of $43 \%$, versus around $70 \%$ for the UK and US before the housing bubble burst and the financial crisis went global. ${ }^{2}$ In the US, mortgages are the primary means of debt-financing for most of the population, including 
home equity withdrawals, although low-income non-homeowners primarily turn to credit card debt (Barba and Pivetti, 2009). Lower homeownership may be an indication of less financialization in Germany. In any case, these data support the argument that the higher growth rates in the US were sustained in part by consumer debt. Macroeconomic demand-regime analysis provides further evidence that the US is a debt-led regime, whereas Germany is an export-led regime (Onaran et al., 2010; Stockhammer, 2012).

\section{Discussion}

The article has developed a theory of dysfunctional accumulation regimes and presented an empirical analysis showing that the model of postfordism as an inherently dysfunctional regime applies to the US, UK and Germany. Table 1 presents a summary of the findings. The postfordist regime in the US has been and continues to be dysfunctional insofar as it has not experienced a sustained recovery in the profit rate (despite a declining wage share for labour) and because it has maintained moderate growth levels for two of its three decades via debt-led growth. Its stagnant growth in the 2000s despite rising household debt suggests more serious problems associated with overproduction. As of 2001, 20\% of the 55 million American homeowners were delinquent on their mortgages or owed more than their house was worth (Greider, 2011), consistent with Stockhammer's (2012) argument about the inherent fragility of debt-led growth.

[TABLE 1 HERE] 
The postfordist regime in the UK has been and continues to be dysfunctional because it has not experienced a sustained recovery in the profit rate (despite a declining wage share for labour) and it has experienced four decades of stagnant growth. Stagnation began in the 1970s while the decline in labour's share and the profit rate recovery both began in 1980, suggesting a shift in the cause of stagnation from the profitrate decline under Fordism to underconsumptionism in the postfordist regime. As a result of declining purchasing power, household debt rose but has not been sufficient to boost growth out of stagnation, suggesting it may not be a debt-led regime, although it is possible that growth would be even more dismal without credit-driven consumption. The answer will have to await future demand-regime analysis.

Finally, the postfordist regime in Germany has been and continues to be dysfunctional because it has not experienced a sustained profit-rate recovery (although it did see a slight rise in the profit rate due to a declining wage share for labour) and because it has experienced three decades of stagnant growth. Its wage share did not begin a sustained decline until 1993, suggesting that the stagnant growth is not driven by underconsumptionism but largely by a consistently low profit rate, likely in combination with overproduction.

Our focus here has been on the macroeconomic analysis of dysfunctional accumulation, but we have emphasised that the underlying mechanisms shaping profit rates and wage shares are rooted in labour market institutions, in particular deunionisation and job polarisation in a service economy. Base on the US case we argued that job polarisation resulted from a new logic of employment externalisation in the form of reduced security, training and promotion opportunities, and market-determined wages. 
In our analysis, these trends, along with neoliberal policies, are not simply one alternative among many, but are necessarily driven by the structural context of postfordist capitalism. Indeed, as Heyes (2011) has shown, employment security has been decreasing across Western European economies, despite flexicurity being the dominant labour market policy prescription of the European Commission. The extent to which a logic of employment externalisation and its cousin, shareholder value, underlies job polarisation in the UK and Germany is an important topic for future research. These labour market outcomes have been driven by competition between capitals and struggle between classes, which, following Clarke (1990-1991), we view as manifestations of a permanent tendency toward overproduction in capitalism. This provides the general context within which the stagnationist tendencies variably become manifest, depending on the state of the class struggle within particular national institutional frameworks. We have provided evidence that Germany is stagnating due to a low profit rate and the UK due to underconsumptionism, while the US diverted underconsumptionist stagnation for the first two decades of postfordism through debt-led growth.

Opponents of underconsumptionism argue that investment demand can produce strong growth as businesses sell to each other (Shaikh, 1978; Kliman, 2012). But as Foster and Magdoff (2009) showed, in the US surplus of capital with a lack of sufficient outlets for productive investment lead to rampant speculation through the development of a raft of esoteric financial instruments, a housing bubble and predatory mortgage lending. And empirical demand-regime models have demonstrated that US growth is debt-led (Onaran et al., 2010). Together, these findings provide strong support for the underconsumptionist argument. But the data from Foster and Magdoff also indicate 
overproduction. Now, it seems clear that financialization in the US played a significant role in the latest crisis by increasing financial instability, more specifically by inflating the housing bubble and setting up the 2007 collapse due to widespread default by subprime mortgage borrowers (Appelbaum, 2011; Stockhammer, 2012). But financialization, including debt-led growth, grew out of the general condition of overproduction: surplus capacity with surplus capital (Foster and Magdoff, 2009).

Our analysis implies that underconsumptionism cannot be easily remedied by redistribution because it was produced through class struggle in the labour market as capital attempted to recover profit rates. In the postfordist regime, any redistribution of income to labour would put downward pressure on profit rates that are already historically low. Similarly, it has been argued by Marxists (e.g. Duménil and Lévy, 2004) and other critical economists (e.g. Stockhammer, 2012) that the primary source of declining wage shares and financialization is neoliberalism. This suggests that the current problems result from policy regime that could be reversed. In contrast, the argument of this article is that dysfunctional accumulation and the maladies it has inflicted on labour and labour markets are fundamentally structural economic problems inherent to the postfordist regime. The reason for using the concept of postfordism is because of the fundamental uniqueness of the Fordist regime. With the demise of Fordism, capitalism has again been unleashed. In the postfordist condition, the prospects for a return to the employment norms and declining inequality of the Fordist period are bleak. The plight of postfordism appears to be long-term and without any institutional fix that is consistent with capitalism as we know it. The time for more widespread consideration of alternatives to capitalism is long overdue. 
${ }^{1}$ Economic Report of the President, 2012, Table B-54.

${ }^{2}$ I am indebted to Ian Greer and Hyunji Kwon for helping me tease out this point. 


\section{References}

Aglietta M (2000 [1979]) A Theory of Capitalist Regulation: The US Experience. London: Verso Classics.

Appelbaum E (2011) Macroeconomic policy, labour market institutions and employment outcomes. Work, Employment \& Society 25(4): 596-610.

Barba A, Pivetti M (2009) Rising household debt: Its causes and macroeconomic implications--a long-period analysis. Cambridge Journal of Economics 33(1): 113-137.

Boyer R (1979) Wage Formation in Historical Perspective: The French Experience. Cambridge Journal of Economics 399-118.

Boyer R (1988) Technical Change and the Theory of 'Régulation'. In: Dosi G, Freeman C, Nelson R, Silverberg G, Soete L (eds) Technical Change and Economic Theory. London: Pinter Publishers Limited,

Boyer R (2000) Is a Finance-led growth regime a viable alternative to Fordism? A preliminary analysis. Economy and Society 29(1): 111-145.

Boyer R, Saillard Y (2002a) Régulation Theory: The State of the Art London: Routledge.

Boyer R, Saillard Y (2002b) A Summary of Régulation Theory. In: Boyer R, Saillard Y (eds) Régulation Theory: The State of the Art. London: Routledge, 36-44.

Clarke S (1990-1991) The Marxist Theory of Overaccumulation and Crisis. Science \& Society 54(4): 442-467.

Crompton R (2010) Class and employment. Work, Employment \& Society 24(1): 9-26.

Dawson P, Webb J (1989) New Production Arrangements: The Totally Flexible Cage? Work, Employment \& Society 3(2): 221-238.

Duménil G, Lévy D (2004) Capital Resurgent: Roots of the Neoliberal Revolution. Cambridge, MA: Harvard University Press.

Fernández-Macías E (2012) Job Polarization in Europe? Changes in the Employment Structure and Job Quality, 1995-2007. Work and Occupations 39(2): 157-182.

Foster JB, Magdoff F (2009) The Great Financial Crisis: Causes and Consequences. New York: Monthly Review Press.

Glyn A, Hughes A, Lipietz A, Singh A (2007) The Rise and Fall of the Golden Age. In: Marglin SA, Schor JB (eds) The Golden Age of Capitalism: Reinterpreting the Postwar Experience. Oxford, UK: Oxford University Press, 39-125. 
Goos M, Manning A (2007) Lousy and Lovely Jobs: The Rising Polarization of Work in Britain. Review of Economics and Statistics 89118-133.

Goos M, Manning A, Salomons A (2009) Job Polarization in Europe. American Economic Review: Papers \& Proceedings 99(2): 58-63.

Gottfried H (2000) Compromising positions: emergent neo-Fordisms and embedded gender contracts. The British Journal of Sociology 51(2): 235-259.

Greider W (2011) It's Time for Debt Forgiveness, American-Style. The Nation (November 14). Harvey D (2010) The Enigma of Capital and the Crises of Capitalism. London: Profile Books. Heyes J (2011) Flexicurity, employment protection and the jobs crisis. Work, Employment \& Society 25(4): 642-657.

Hyman R (1987) Strategy or Structure? Capital, Labour and Control. Work, Employment \& Society 1(1): 25-55.

Kliman A (2012) The Failure of Capitalist Production: Underlying Causes of the Great Recession. London: Pluto Press.

Lane C (1988) Industrial Change in Europe: The Pursuit of Flexible Specialisation in Britain and West Germany. Work, Employment \& Society 2(2): 141-168.

Lapavitsas C (2011) Theorizing financialization. Work, Employment \& Society 25(4): 611-626.

Lazonick W, O'sullivan M (2000) Maximizing shareholder value: a new ideology for corporate governance. Economy and Society 29(1): 13-35.

Lipietz A (1982) Towards Global Fordism? New Left Review I/132(March-April): 31-47.

Lipietz A (1986) Behind the Crisis: The Exhaustion of a Regime of Accumulation. A 'Regulation School' Perspective on Some French Empirical Works. Review of Radical Political Economics 18(1\&2): 13-32.

Lipietz A (1992) Towards a New Economic Order: Postfordism, Ecology and Democracy. Cambridge, UK: Polity Press.

Marx K (1981 [1894]) Capital, Vol. 3. London: Penguin.

Marx K (1992 [1885]) Capital, Vol. 2. London: Penguin.

Mohun S (2006) Distributive shares in the US economy, 1964-2001. Cambridge Journal of Economics 30(3): 347-370.

Mohun S (2009) Aggregate capital productivity in the US economy, 1964-2001. Cambridge Journal of Economics 33(5): 1023-1046. 
Onaran Ö, Stockhammer E, Grafl L (2010) Financialisation, income distribution and aggregate demand in the USA. Cambridge Journal of Economics 35(4): 637-661.

Palloix C (1976) Le Procès de Travail. Du Fordisme au Néofordisme. La Pensée (185).

Piore MJ, Sabel CF (1984) The Second Industrial Divide: Possibilities for Prosperity. New York: Basic Books.

Sabel CF (1982) Work and Politics: The Division of Labor in Industry. Cambridge: Cambridge University Press.

Shaikh A (1978) An Introduction to the History of Crisis Theories. In: Crisis Reader Editorial Collective (ed.) U.S. Capitalism in Crisis. New York: URPE, 219-241.

Shaikh A (1987) The Falling Rate of Profit and the Economic Crisis in the US. In: Cherry R, Moseley F, D'onofrio C, Kurdas C, Michl TR, Naples MI (eds) The Imperiled Economy: Macroeconomics from a Left Perspective. New York: Union for Radical Political Economists, 115-126.

Smith C (1989) Flexible Specialisation, Automation and Mass Production. Work, Employment \& Society 3(2): 203-220.

Stockhammer E (2012) Financialization, Income Distribution and the Crisis. investigación económica LXXI(279): 39-70.

Streeck W (1987) The Uncertainties of Management in the Management of Uncertainty: Employers, Labor Relations and Industrial Adjustment in the 1980s. Work, Employment \& Society 1(3): 281-308.

Thompson P (2003) Disconnected Capitalism: Or Why Employers Can't Keep Their Side of the Bargain. Work, Employment \& Society 17(2): 359-378.

Tickell A, Peck JA (1992) Accumulation, regulation and the geographies of post-Fordism: missing links in regulationist research. Progress in Human Geography 16(2): 190-218.

Vidal M (2011) Reworking Postfordism: Labor Process versus Employment Relations. Sociology Compass 5(4): 273-286.

Vidal M (2012) On the Persistence of Labor Market Insecurity and Slow Growth in the US:

Reckoning with the Waltonist Growth Regime. New Political Economy 17(5): 543-564.

Vidal M (forthcoming) Low-autonomy work and bad jobs in postfordist capitalism. Human Relations. 
Williams K, Haslam C, Williams J (1992) Ford Versus Fordism: The Beginning of Mass Production? Work, Employment and Society 6(4): 517-555.

Wolff EN (2003) What's behind the rise in profitability in the US in the 1980s and 1990s? Cambridge Journal of Economics 27(4): 479-499.

Wright EO, Dwyer RE (2003) The patterns of job expansions in the USA: a comparison of the 1960s and 1990s. Socio-Economic Review 1(3): 289-325. 
TABLE 1: Sources of dysfunctional accumulation in postfordism

\begin{tabular}{llll}
\hline \multicolumn{1}{c}{ Manifest stagnationist tendencies } & US & UK & Germany \\
\hline Declining profit rate & Yes & Yes & Yes \\
Underconsumptionism & -- & Yes & -- \\
Debt-led growth & Yes & Possibly & -- \\
\hline
\end{tabular}

FIGURE 1: Profit rates, US

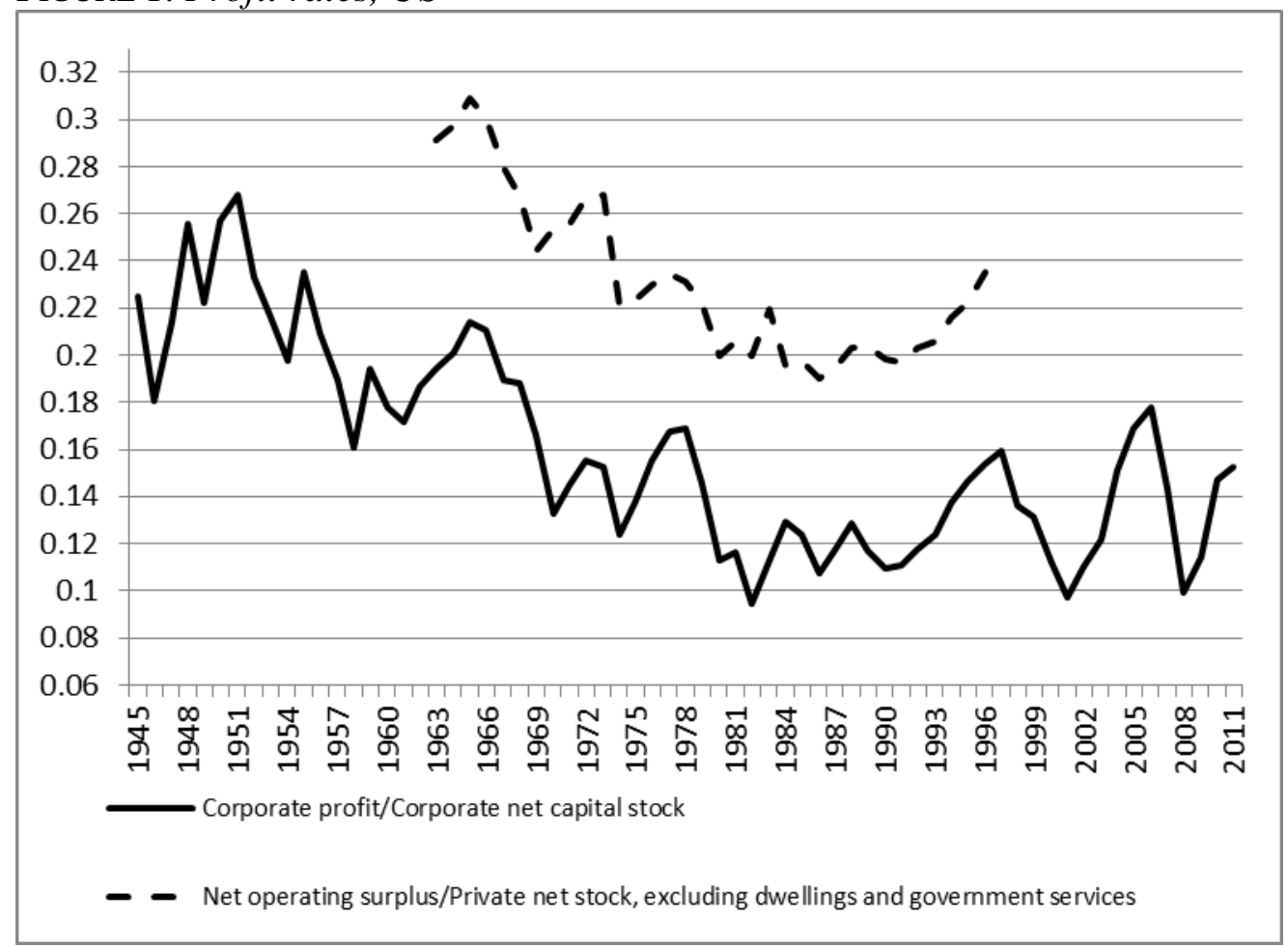

Source: For corporate: US Bureau of Economic Analysis (NIPA Table 1.14, line 11); Fixed Assets (Table 6.3, line 2). For total economy: National Accounts of OECD Countries, Volume II, Detailed Tables, 1963-1969, print; OECD iLibrary, 1970-1996; Flows and Stocks of Fixed Capital, 1963-1996, print. 
FIgURE 2: Profit rates, UK

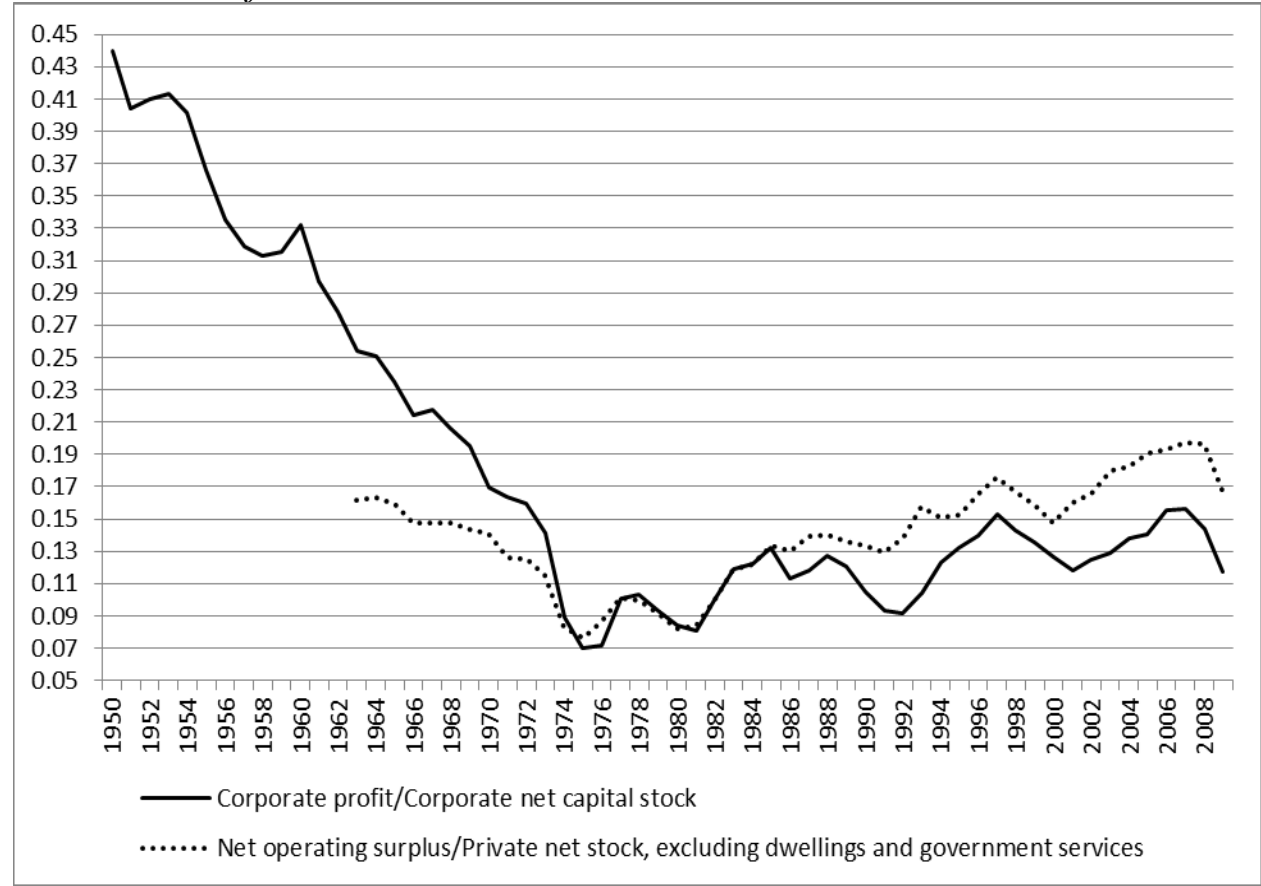

Source: For corporate: Historical data on gross operating surplus, consumption of fixed capital, and net capital stock, all for private nonfinancial and financial corporations, provided by various members of the UK Office of National Statistics. For total economy: National Accounts of OECD Countries, Volume II, Detailed

Tables, 1963-1969, print; OECD iLibrary, 1970-2009; Flows and Stocks of Fixed Capital, 1963-1993, print; UK ONS, 1994-2009.

FIGURE 3: Profit rates, Germany

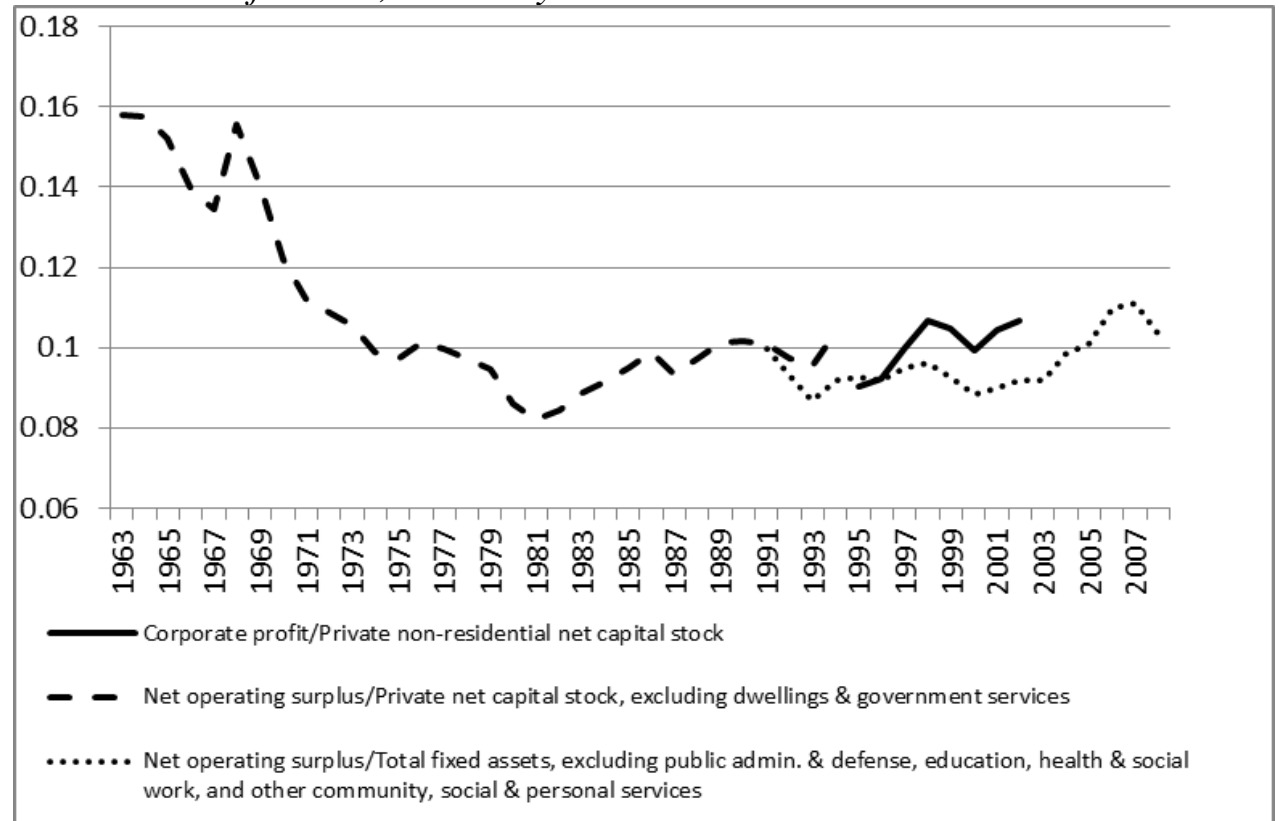

Source: For corporate: OECD iLibrary; Database on Capital Stocks in OECD Countries, Kiel Institute for the World Economy. For total economy: OECD iLibrary, 1963-2008; Flows and Stocks of Fixed Capital, 1963-1994, print; OECD iLibrary, 1991-2008. 
FIGURE 4: Labour's share of national income and union density, 1960-2011
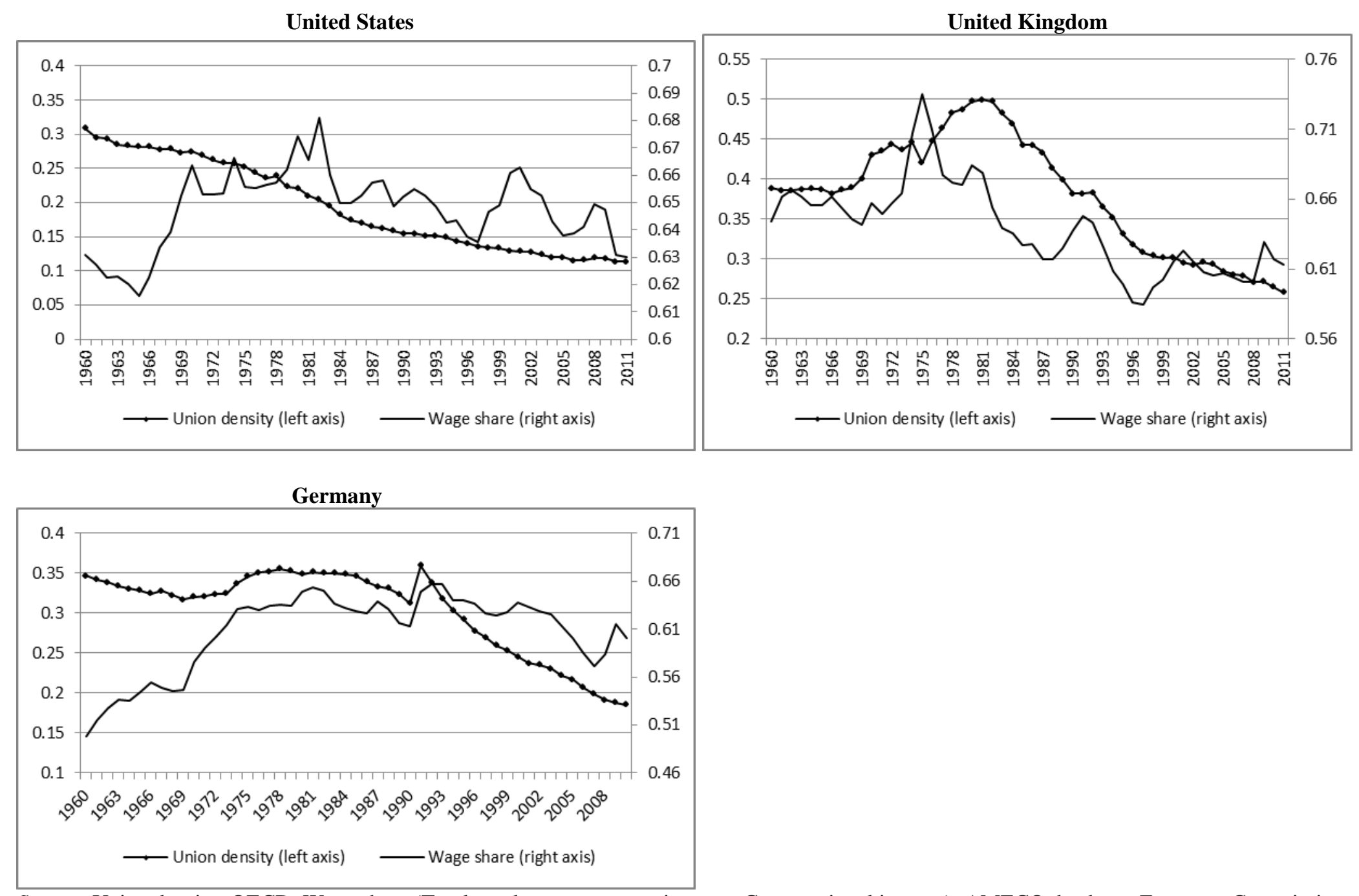

Source: Union density: OECD. Wage share (Total employee compensation over Gross national income): AMECO database, European Commission. 
FIGURE 5: Average decennial GDP growth

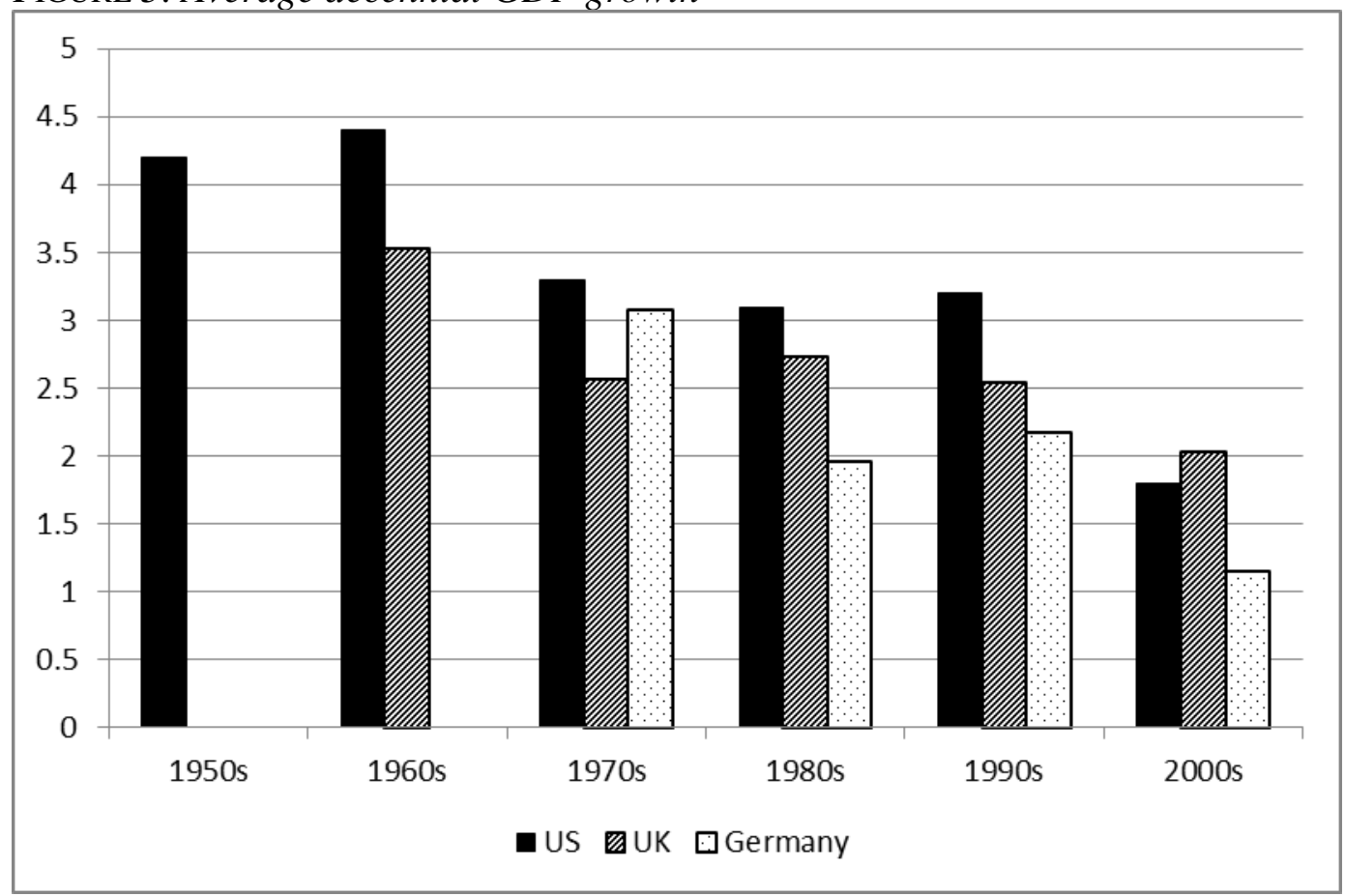

Source: BEA (US), ONS (UK), World Bank (Germany).

FIGURE 6: Household debt to income ratios, 1995-2007

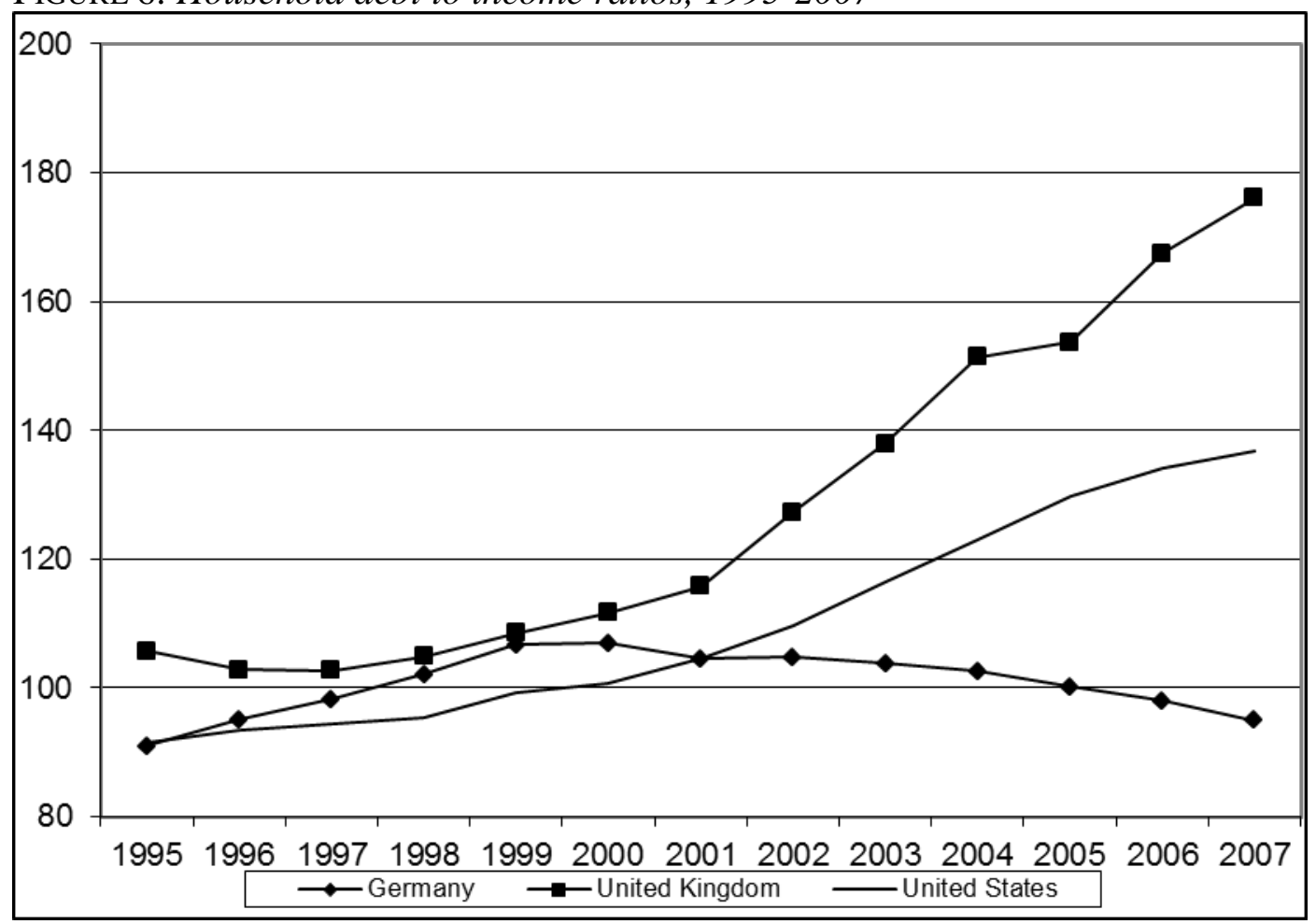

Source: OECD; Eurostat

Note: For a longer-term view, the US household debt ratio was 34\% in 1950 and 58\% in 1960. 


\section{Acknowledgements}

I've received helpful feedback on various versions of this paper from a number of people. Matt Nichter has significantly helped shape my thinking on these issues by providing tireless, sage counsel on nearly every question or idea I've had about Marxism for years. Mark Stuart provided sharp commentary in addition to ruthless editing, both of which substantially improved the paper. I also received insightful criticism and suggestions from Olivier Butzbach, Ian Greer, Hyunji Kwon, Özlem Onaran, Engelbert Stockhammer and three anonymous reviewers. Finally, I would like to thank the UK Office for National Statistics for help with various historical data series on UK national economic accounts.

\section{Bio}

Matt Vidal is Lecturer in Work and Organizations at King's College London, Department of Management. His research interests span the sociology of work and employment, organizations, labor markets, and comparative political economy. Matt's work has been published in Critical Sociology, Industrial Relations, New Political Economy, Socio-Economic Review and Sociology

Compass. He is co-editor of a forthcoming book on Comparative Political Economy of Work and Employment Relations (Palgrave). He is also co-editor of the "Organisations \& Work" section of Sociology Compass, editor-in-chief of "Work in Progress," the blog for the Organizations, Occupations and Work section of the American Sociological Association, and a member of the editorial board of Work, Employment \& Society. 